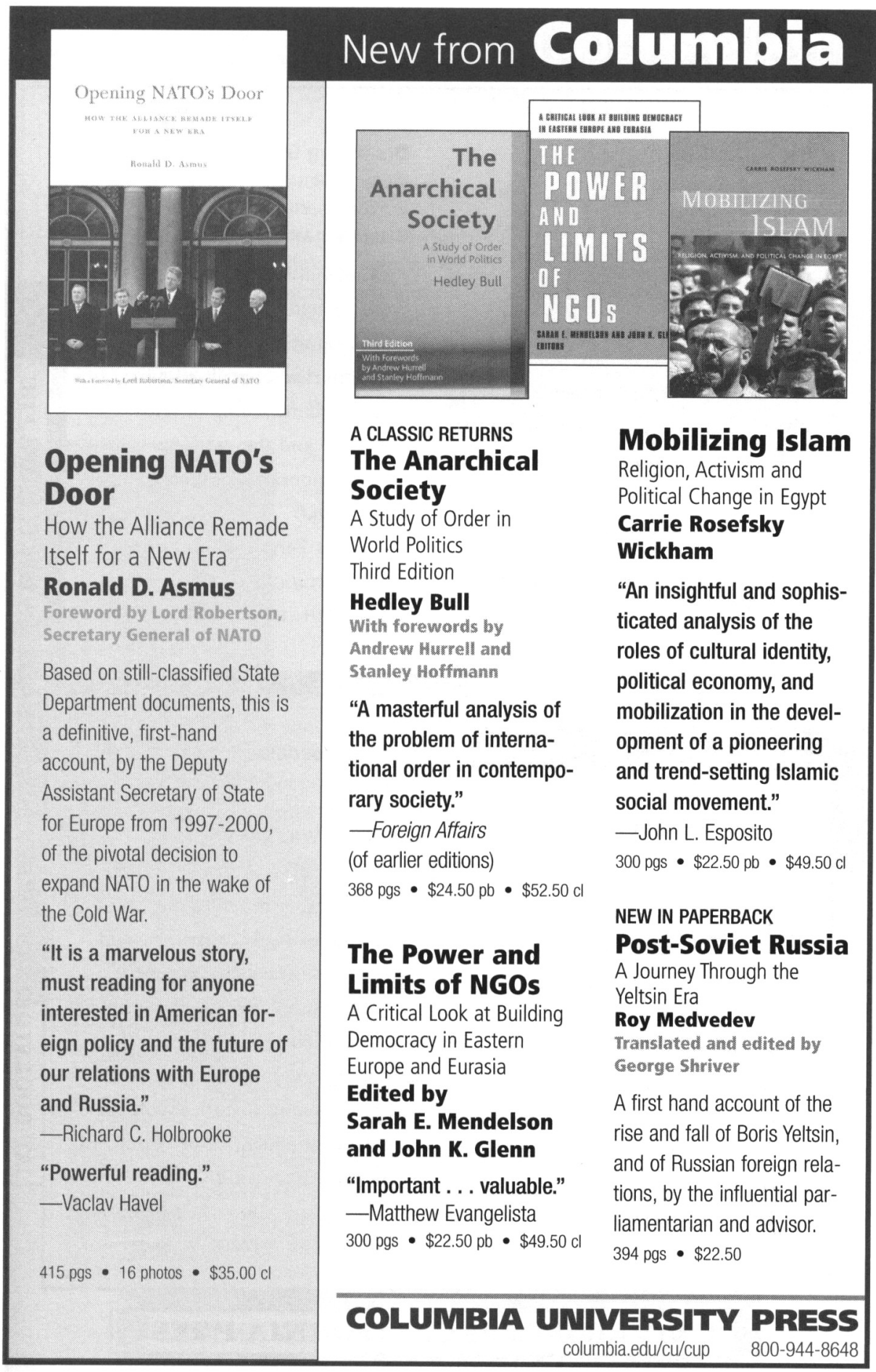




\section{New from California}

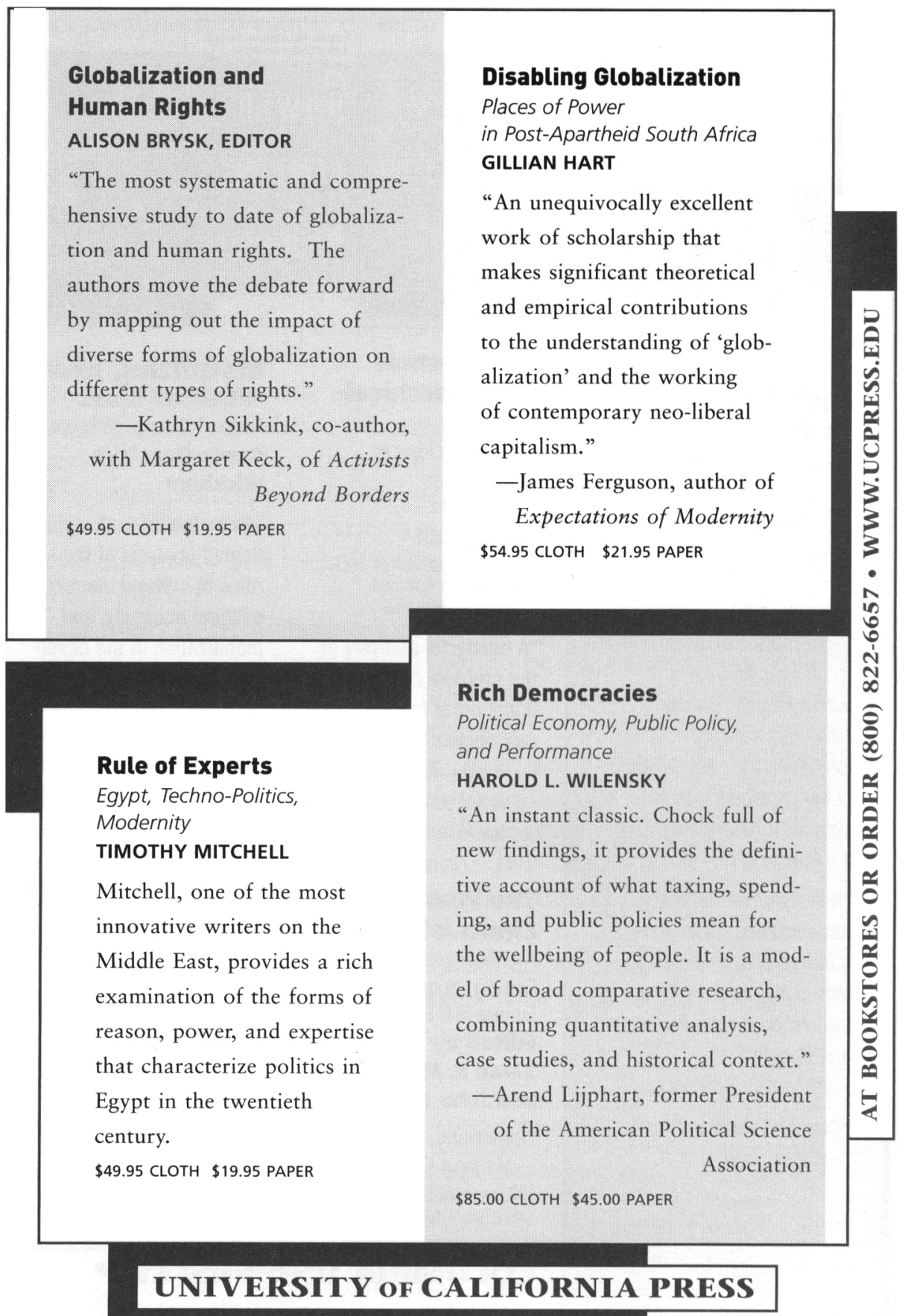




\section{New from California}

\section{Mexico's Mandarins}

Crafting a Power Elite for

the Twenty-First Century

RODERIC AI CAMP

"This unique study offers the first thorough investigation of Mexico's power elites and, for the first time, identifies the essential role played by mentors in the Mexican system of recruiting, promoting, and facilitating the power elites."

-William H. Beezley, author of

The Oxford

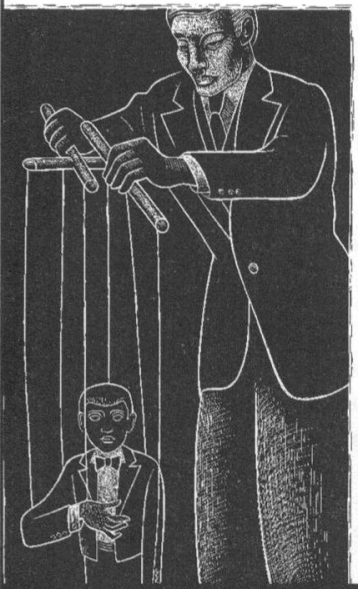

History of Mexico

$\$ 54.95 \mathrm{CLOTH}$

$\$ 21.95$ PAPER

\section{Ho Chi Minh}

The Missing Years

\section{SOPHIE QUINN-JUDGE}

"A thoroughly researched and elegantly written account of what is arguably the most important topic in modern Vietnamese political history....A vivid, nuanced portrait of Ho Chi Minh." -Peter Zinoman, author of The Colonial Bastille

$\$ 39.95 \mathrm{CLOTH}$

\section{Building the Fourth Estate}

Democratization and the Rise of a Free Press in Mexico

\section{CHAPPELL LAWSON}

“Lawson's book...raises extremely interesting questions about the media's influence on emerging democracies that should be of wide interest well beyond the community of Mexico specialists.”-Dan Hallin, author of The "Uncensored

NEW IN PAPERBACK

$\$ 50.00 \mathrm{CLOTH} \$ 19.95$ PAPER

The Challenge of Fundamentalism

Political Islam and

The Deadly Ethnic Riot

the New World Disorder

DONALD L. HOROWITZ

BASSAM TIBI

UPDATED EDITION

"Makes an important contribution to our understanding

"A powerful and important arguof ethnic conflict [and] will be ment, one all the more effective a source of testable hypotheses for years to come."

-American Political from Syria.... [A] brave and brilliant analysis." -Middle East Quarterly Science Review 


\section{OUTSTANDING SCHOLARSHIP FROM CAMBRIDGE}

The Critique of the State

Jens Bartelson

$0-521-80665-8 \mathrm{Hb} \$ 60.00$

$0-521-00140-4 \mathrm{~Pb} \$ 22.00$

\section{A Theory of the State}

Economic Rights

Legal Rights, and the

Scope of the State

Yoram Barzel

0.521-80605-4 Hb $\$ 60.00$

0.521-00064-5 Pb $\$ 22.00$

\section{Nationalist}

Mobilization and

the Collapse of the

Soviet State

Mark R. Beissinger

0-521-80670-4 Hb $\$ 80.00$

$0.521-00148-\mathrm{X} \mathrm{Pb} \$ 30.00$

\section{The Dynamics of Coercion}

American Foreign Policy and the Limits of Military Might

Daniel Byman

and Matthew Waxman

0-521-80991-6 Hb $\$ 65.00$

0-521-00780-1 Pb $\$ 23.00$

\section{Intervention}

and Transnationalism

\section{in Africa}

Global-Local

Networks of Power

Thomas Callaghy,

Ronald Kassimir, and Robert Latham, Editors

$0-521-80666-6 \mathrm{Hb} \$ 70.00$

$0.521-00141-2 \mathrm{~Pb} \$ 25.00$

\author{
Historical Sociology \\ of International \\ Relations \\ Stephen Hobden and \\ John M. Hobson, Editors \\ 0-521-80870-7 Hb $\$ 70.00$ \\ 0-521-00476-4 Pb $\$ 25.00$
}

\section{Crony Capitalism}

Corruption and

Development in South Korea and the Philippines

David C. Kang

$0-521-80817-0$ Hb $\$ 60.00$

$0-521-00408-\times \quad \mathrm{Pb} \$ 23.00$

\section{The European}

Parliament and

Supranational

Party System

A Study in Institutional
Development

Amie Kreppel

0-521-80625-9 Hb $\$ 60.00$

0-521-00079-3 Pb $\$ 22.00$

\section{State in Society}

Studying How States and

Societies Transform and

Constitute One Another

joel S. Migdal

$0-521-79286-X$ Hb $\$ 65.00$

$0-521-79706-3 \mathrm{~Pb} \$ 23.00$

\section{Legislative Politics} in Latin America

Scott Morgenstern and Benito Nacif, Editors

0-521-79219-3 Hb $\$ 65.00$ 0-521-79659-8 Pb $\$ 25.00$

\section{CAMBRIDGE}

UNIVERSITY PRESS

Call toll-free 800-872-7423 www.cambridge.org

Clientelism, Interests, and Democratic Representation

The European Experience

in Historical and

Comparative Perspective

Simona Piattoni, Editor

0-521-80033-1 Hb $\$ 60.00$

0-521-80477-9 Pb $\$ 22.00$

\section{Democracy and} Coercive Diplomacy

Kenneth A. Schultz

$0-521-79227-4 \mathrm{Hb} \$ 65.00$

$0-521-79669-5$ Pb $\$ 23.00$

Ethics and

Foreign Policy

Karen E. Smith

and Margot Light, Editors

0-521-80415-9 Hb $\$ 60.00$

$0-521-00930-8 \mathrm{~Pb} \$ 22.00$

\section{Public Support for} Market Reforms in New Democracies

Susan C. Stokes, Editor $0-521-66339-3 \mathrm{Hb} \$ 60.00$ 0-521-66341-5 Pb $\$ 22.00$

\section{African Economies} and the Politics of Permanent Crisis, 1979-1999

Nicolas van de Walle 0-521-80364-0 Hb $\$ 60.00$ $0-521-00836-0 \mathrm{~Pb} \$ 20.00$

\section{Money and Security}

Troops, Monetary Policy, and West Germany's

Relations with the United States and Britain, 1950-1971

Hubert Zimmermann $0-521-78204-X$ Hb $\$ 45.00$ 


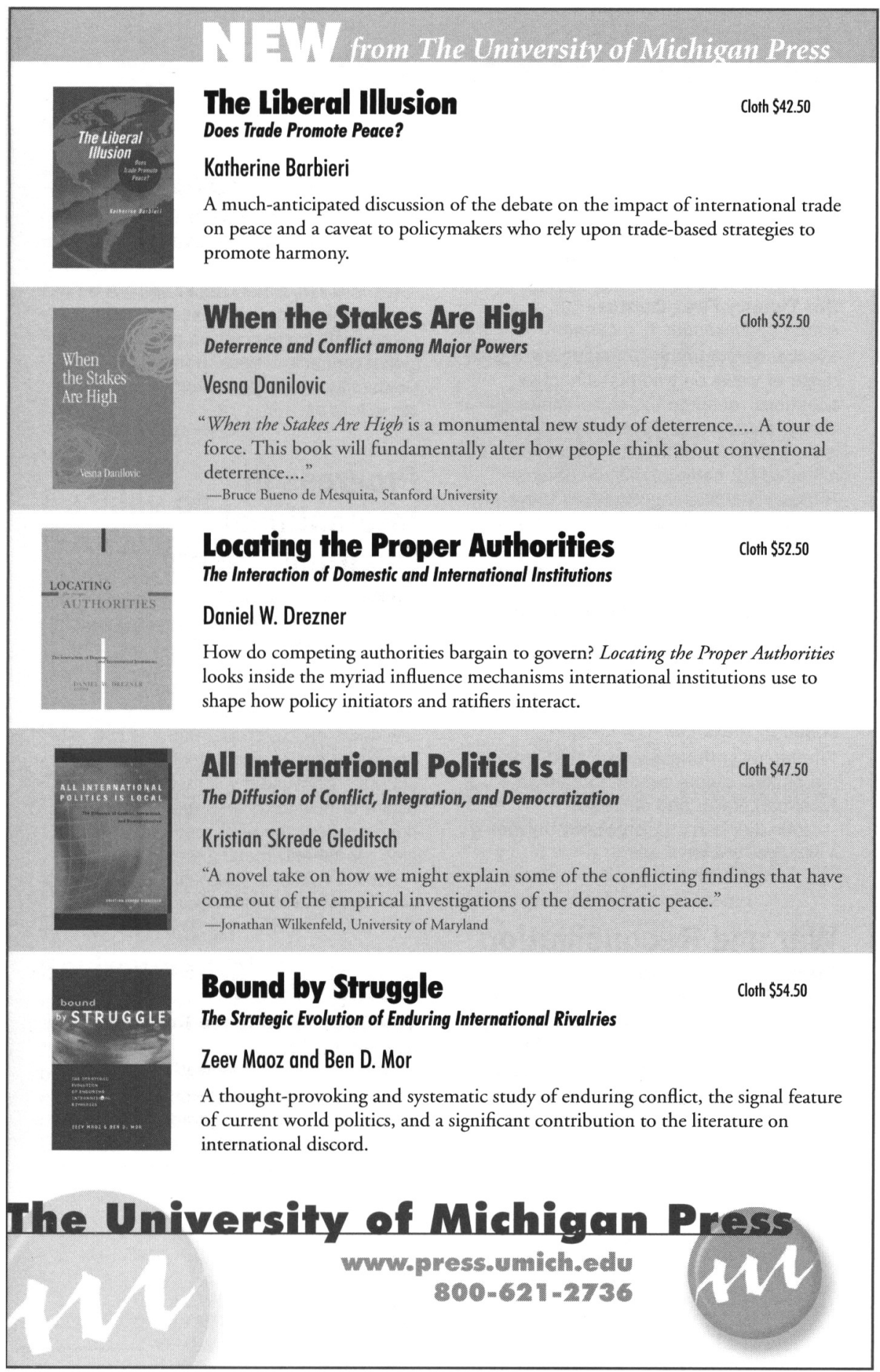




\section{new from The MIT Press}

\section{Contemporary Nuclear Debates}

Missile Defenses, Arms Control, and Arms Races in

\section{the Twenty-First Century}

edited by Alexander T. J. Lennon

"Succeeds admirably in presenting a wide range of views on traditional nuclear questions recast in the current international environment. Especially noteworthy is its treatment of the potential impact of a limited US national missile defense."

- Dean A. Wilkening, Stanford University A Washington Quarterly Reader 270 pp. \$24.95 paper

\section{What Does the World Want from America?}

\section{International Perspectives}

on U.S. Foreign Policy

edited by Alexander T. J. Lennon

"These insightful essays nicely illuminate the shifting global sentiments about American power and purpose."

- John Ikenberry, Georgetown University A Washington Quarterly Reader 200 pp. \$22.95 paper

\section{War and Reconciliation}

\section{Reason and Emotion in Conflict Resolution}

William J. Long and Peter Brecke

"This is an exciting and important book, which contributes profoundly to integrating two increasingly significant matters: the attainment of durable peaceful relations after violent conflict, and the synthesis of evolutionary psychology with major streams of social science theory."

- Louis Kriesberg, Syracuse University 224 pp., 12 illus. \$22.95 paper

\section{Media and Sovereignty}

The Global Information Revolution and Its Challenge to State Power Monroe E. Price

"This is a very timely book, and will be of considerable interest to all who are concerned with media culture and policy in global times." - Kevin Robins, Goldsmiths College, University of London 320 pp. $\$ 29.95$

\section{Progress in International Relations Theory}

\section{Appraising the Field} edited by Colin Elman and Miriam Fendius Elmain foreword by Kenneth N. Waltz

"An in-depth exploration of progress in international relations theory in the past few decades. ... This volume is critically important for international relations scholars because it will make them more aware of how to assess research, and how to select the best research strategies for actually making progress." - Helen V. Milner, Columbia University BCSIA Studies in International Security 400 pp. $\$ 24.95$ paper

\section{Going Alone}

\section{The Case for Relaxed Reciprocity} in Freeing Trade

edited by Jagdish Bhagwati

"This is a pathbreaking work on the common practice of freeing trade unilaterally. ... a seminal and definitive work." - T. N. Srinivasan, Yale University 654 pp., 14 illus. $\$ 60$ 


\section{Greening the Americas}

\section{NAFTA's Lessons}

for Hemispheric Trade

edited by Carolyn L. Deere

and Daniel C. Esty

foreword by José Maria Figueres-Olsen

“Charts a realistic course for designing new trade agreements that draw upon the strengths and avoid the mistakes of NAFTA. For those of us who see the trade and environment nexus as central to future progress, this is essential reading." - William K. Reilly, former Administrator, U.S. Environmental Protection Agency

352 pp., 10 illus. $\$ 27.95$ paper

\section{Banking on the Environment}

Multilateral Development Banks and Their Environmental Performance in Central and Eastern Europe

Tamar L. Gutner

"An important study of some of the challenges international institutions face in responding to increasingly diverse demands from their expanding constituencies." - Steven Weber, University of California, Berkeley 280 pp., 4 illus. $\$ 24.95$ paper

\section{Moral and Political Reasoning in}

\section{Environmental Practice}

edited by Andrew Light and Avner de-Shalit

"This balanced and brilliant collection bridges environmental philosophy and environmental practice to the betterment of both." - Mark Sagoff, University of Maryland 344 pp., 3 illus. \$27.95 paper

\section{The Economics of the World Trading System}

Kyle Bagwell and Robert W. Staiger

"This book is a key source for anyone interested in GATT and the WTO, not only economists but also political scientists and international law scholars."

- Giovanni Maggi, Princeton University 224 pp., 13 illus. $\$ 29.95$

\section{Multinational Firms and the Theory of International Trade}

James R. Markusen

"Markusen has penned a dream book on multinationals for students and specialists alike. The questions are essential, the results rich, and the exposition exquisite." - Donald R. Davis, Columbia University 456 pp., 79 illus. $\$ 45$

\section{Environmental Politics and Policy in Industrialized Countries} edited by Uday Desai

"The first really useful book for teaching comparative environmental politics."

- Norman Vig, Carleton College 392 pp., 3 illus. $\$ 24.95$ paper

\section{The Middle East Military Balance, 2001-2002}

Shlomo Brom and Yiftah Shapir

"Provides the most comprehensive and objective analysis of Middle East military developments available in the open literature. A first-rate product."

- Geoffrey Kemp, Director of Regional Strategic Programs, The Nixon Center 462 pp. $\$ 37.95$

http://mitpress.mit.edu 


\section{Armed Humanitarians}

U.S. Interventions from

Northern Iraq to Kosovo

\section{Robert C. DiPrizio}

"This is a clearly written and easy to follow account of American humanitarian interventions in the post-Cold War era, focusing on the motivations for Presidents Bush and Clinton to intervene or (as in the case of Rwanda) not to intervene in response to a humanitarian crisis."-Steven R. David, Johns Hopkins University \$19.95 paperback

\section{The Legacies of Liberalism}

Path Dependence and Political Regimes in Central America James Mahoney

"Mahoney presents a bold and multilayered argument that links developments across the nineteenth and twentieth centuries, supported through a systematic comparative analysis of all five Central American countries. The Legacies of Liberalism is the most important book on Central America written in the last ten years."

- Gerardo Munck, University of Illinois at Urbana-Champaign, author of Authoritarianism and Democratization: Soldiers and Workers in Argentina, 1976-1983

\section{Democracy after Communism}

\section{edited by Larry Diamond and Marc F. Plattner}

Was the process that brought down communism in Eastern Europe and the former Soviet Union fundamentally different from the process that gave birth to new democracies in other regions of the world? Is the challenge of building and consolidating democracy under postcommunist conditions unique, or can one apply lessons learned from other new democracies? The essays collected in this volume explore these questions, while tracing how the countries of Eastern Europe and the former Soviet Union have fared following the fall of communism.

A Journal of Democracy Book $\$ 18.95$ paperback

\section{Paradoxes of Democracy}

Fragility, Continuity, and Change Shmuel N. Eisenstadt

"His analysis ... is a welcome reminder that constitutions have to survive in the face of incalculable changes."-Jeremy Waldron, Times Literary Supplement

"The book is a tour de force of the highest order and addresses itself to one of the hottest market areas of the field, to students of democracy in sociology, political science, and history of ideas."-Zoltán Tarr, Contemporary Sociology

Woodrow Wilson Center Press $\$ 18.95$ paperback

$\$ 18.95$ paperback 